\title{
Competitive Priorities and Competitive Advantage in Jordanian Manufacturing
}

\author{
Abdulkareem S. Awwad ${ }^{1}$, Adel A. Al Khattab ${ }^{2}$, John R. Anchor ${ }^{3}$ \\ ${ }^{1}$ Department of Management and Marketing, College of Business \& Economics, University of Qatar, Doha, Qatar; ${ }^{2}$ Department of \\ Business, College of Business Administration, Al-Hussein Bin Talal University, Ma'an, Jordan; ${ }^{3}$ Department of Strategy and Mar- \\ keting, Business School, University of Huddersfield, Huddersfield, UK. \\ Email: a.awwad@qu.edu.qa, adel.alkhattab@yahoo.co.uk,j.r.anchor@hud.ac.uk
}

Received December $7^{\text {th }}, 2012$; revised January $10^{\text {th }}, 2013$; accepted January $22^{\text {nd }}, 2013$

\begin{abstract}
The purpose of this research was to explore and predict the relationship between the competitive priorities (quality, cost, flexibility and delivery) and the competitive advantage of firms in the Jordanian Industrial Sector. A population of 88 Jordanian manufacturing firms, registered on the Amman Stock Exchange, was targeted using a cross-sectional survey employing a questionnaire method of data collection. The results of the data analysis indicate a significant relationship between competitive priorities and competitive advantage. The research suggests that recognising and nurturing this relationship provides the master key for a firm to survive in a turbulent environment. Therefore, operational and marketing strategies should place emphasis on competitive priorities such as quality, cost, flexibility and delivery to achieve, develop and maintain competitive advantage. This study is one of the first to examine the relationship between the competitive priorities of Jordanian manufacturing firms and their competitive advantage.
\end{abstract}

Keywords: Quality; Flexibility; Competitive Priorities; Competitive Advantage; Manufacturing; Jordan

\section{Introduction}

There exists a rich body of knowledge on the nature and causes of competitive advantage and competitive priorities in the strategy literature, ranging from the industry positioning approach and the commitment explanation to the resource-based view and the dynamic capability approach [1]. The concept of competitive advantage needs to be tested empirically to determine the competitive priorities which create a firm's competitiveness. However, little empirical work has been undertaken to address this issue. In this context, [2] states that "there are [few] empirically derived taxonomies that characterise manufacturers by manufacturing tasks or competitive priorities, such as quality, delivery, flexibility, or cost". There is a need, therefore, to conduct empirical studies which address and analyse the functions and processes which create the competitive advantage of a firm.

\section{Literature Review}

\subsection{Competitive Advantage}

As firms are forced to respond efficiently and effectively to a changing business environment, one of the strongest challenges that firms face is gaining and developing competitive advantage, which may be defined as the ex- tent to which a firm is able to create and maintain a defensible position over its competitors [3]. Alternatively, it may be considered to refer to the capabilities which allow a firm to shape its competitive advantage so defined and differentiate itself from its competitors [4]. In the same vein, [5] defines competitive advantage as the asymmetry or differential in any attribute or factor that allows a firm to serve its customers more effectively than others and hence to create better customer value and achieve superior performance. Reference [6] suggests that competitive advantage is achieved by the competetiveness of the supply chain, which means "meeting end customer demand through supplying what is needed in the form it is needed, when it is needed, at a competitive cost".

Creating competitive advantage requires a determination of the factors that may put a firm in a better position in relation to its competitors in the marketplace. Four strategic capabilities which can be considered as competitive priorities are identified by $[7,8]$; low cost, quality, quick delivery and flexibility. Alternatively, competitive advantage, as identified by [9], is derived from five sources of innovation: new technologies; the modification of demand or the emergence of new demand; the emergence of a new segment; changes in costs or the availability of 
means of production; and changes in regulation. In the same vein, [10] considers that quality and productivity can be used as strategic weapons to achieve competitive advantage. Firms, as recommended by [10], must be aware of what increases quality or supports production as strategic weapons; otherwise, firms will lose market share.

By contrast, [11] considers the key to competitive advantage to be competencies, which are defined as a combination of resources and capabilities. From a strategic perspective, competences can be functions, processes and routines in a firm. Competence is a controversial concept, since it has been identified using different perspectives, but is central to the domains of both strategy and human resource management (HRM) [11]. Competences, as argued by [12], can be classified into two categories: personal competences, such as knowledge, skills, abilities, experience and personality, and corporate competences, which belong to the firm and are embedded processes and structures that tend to reside within it. Reference [13] adds that top management needs to have specific competences including leadership skills, general management skills, interpersonal skills, communication skills, creativity and personality traits such as dependability and adaptability.

Reference [14] proposes the use of the following variables to determine firms' competitiveness: market share, profits, returns, technological provision, financial management, quality of products/services, after-sales service, managers' educational background, customer loyalty, supplier loyalty, location of establishment, employees' commitment and loyalty, employees' professional knowhow, and reputation. The resource-based view (RBV) of the firm considers it to be a collection of assets or resources. These may be tangible assets such as physical capital, brand names or fewer tangible assets, such as organisational routines and capabilities. Resources may be both static and dynamic. The crucial requirement of the RBV is that the relevant resources, whatever their nature, are specific to the firm and not easily imitated by rivals [15].

The sustainable competitive advantage (SCA) approach to the RBV is illustrated by the work of $[16,17]$. SCA theory seeks to explain the extent to which a firm may be able to sustain a position of competitive advantage. This depends on the ownership of firm-specific resources that are valuable, rare, inimitable and nonsubstitutable (VRIN) [16]. However, in practice, [18] argue that there are significant methodological and practical difficulties associated with identifying a relationship between a firm's resource endowment and its competitive advantage. Reference [19] explains that the RBV was not able to explain how some firms were able to respond flexibly and in a timely manner to changes in their external environment by re-deploying both internal and external competences. Reference [20] goes on to define dynamic capabilities as the firm's ability to integrate, build and reconfigure internal and external competences to address rapidly changing environments. Dynamic capabilities thus allow firms to maintain a competitive advantage and may help them to avoid developing core rigidities, which inhibit development, generate inertia and stifle innovation. A dynamic capability is not, therefore, a capability in the RBV sense. Indeed, it is not a resource; rather, it is a process which impacts upon and alters the resource base.

The literature is divided about the relationship between dynamic capabilities and competitive advantage. The problem is that these definitions are often tautological. Reference [21] explains that if the firm has a dynamic capability, it must perform well, and if the firm is performing well, it should have a dynamic capability. As [22] suggest, dynamic capabilities do not necessarily lead to competitive advantage. While dynamic capabilities may change the resource base, this renewal may not necessarily be valuable, since it may not create any VRIN resources. Indeed, there may be four different outcomes of the deployment of dynamic capabilities. First, dynamic capabilities may lead to sustainable competitive advantage if the resulting resource base is not initiated for a long time and economic rents are sustained. Second, they may lead to a temporary advantage, especially in hypercompetitive environments. Third, they may only give competitive parity if their effect on the resource base simply allows the firm to operate in the industry, rather than to outperform rival firms. Finally, the development of dynamic capabilities may lead to failure if the resulting resource stock is irrelevant to the market.

Furthermore, if there is no direct link between dynamic capabilities and competitive advantage, it can be suggested that dynamic capabilities do not have to be firm-specific. Indeed, dynamic capabilities can be duplicated across firms; therefore their value for competitive advantage lies in the resource configuration which they create, not in the dynamic capabilities themselves [23].

\subsection{Competitive Priorities}

The literature on operations strategy and manufacturing strategy has addressed extensively the competitive priorities which act as strategic capabilities and which can help firms to create, develop and maintain competitive advantage. Competitive priorities are defined as the dimensions that a firm's production system must possess to support the demands of the markets in which the firm wishes to compete [24]. Reference [25] identifies six criteria which act as competitive priorities: quality, cost, delivery, flexibility, customer focus and know-how. Ref- 
erence [25] defines these criteria as follows:

1) Quality: Low defect rate, product performance, reliability, certification and environmental concern.

2) Cost: The ability to manage effectively production cost, including its related aspects such as overhead and inventory, and value-added.

3) Delivery which is considered a time-based issue. Delivery addresses how quickly a product or a service is delivered to customers. It also incorporates the time-tomarket for a new product.

4) Flexibility: This term represents the ability to deploy and/or re-deploy resources in response to changes in contractual agreements which are initiated primarily by customers. It includes several features, such as adjustment to design/planning, volume changes and product variety.

5) Customer focus: This concentrates on how to fulfil customers' needs. It includes after-sale services, product customisation, product support, customer information and dependable promise.

6) Know-how: This deals with the trend of decreasing product lifecycles. Therefore, knowledge management, creativity and skills development are included.

Like $[8,26]$ concludes that there is general agreement that the major competitive priorities comprise the following elements: flexibility, cost, quality and delivery.

\subsubsection{Flexibility}

Reference [27] defines flexibility as the ability to respond effectively to changing circumstances. The work of [27] has been extended and supported by a number of authors. References [28-30] agree on the importance of flexibility in coping with uncertainty. The similarities of the definitions of flexibility, however, refer to the term main job, which is mastering changes and meeting uncertainty resulting from the internal and external business environments. In this context, [29] defines flexibility as a quick response to changed production volume, changed product mix, customisation of product (i.e. providing each customer with what she wants), introduction of new products and adoption of new technology. Reference [30] supports the definition of flexibility by [26] as the ability to change or react with little penalty in time, effort, cost or performance. It may be concluded that both [26] and [30] have focused on coping with changes efficiently and effectively. In other words, efficiency and effectiveness are the basic criteria for measuring performance, where organisational goals should be met at lower cost and with higher utilisation of resources. Reference [31] states that the definition of [27] consists of three main elements: The first element is "ability", which gives flexibility the character of a potential. The second is "to respond"; response generally means reaction or adaptation to changes. Finally, "effectively" suggests a link between the concept of flexibility and the concept of the overall performance of the system.

Flexibility, however, is a multidimensional concept [32]. Therefore, flexibility is classified in the literature using different dimensions. Reference [31] suggests that different kinds of flexibility would be appropriate to deal with different conditions or types of change. Reference [30] classifies flexibility into two forms: action flexibility (the capacity for taking new action to meet new circumstances) and state flexibility (the capacity to continue functioning effectively despite changes in the environment). Reference [33], in his taxonomy, identifies two classes of flexibility: job flexibility is the ability of the system to cope with changes in jobs to be processed by a system, while machine flexibility is the ability of a system to cope with changes and disturbances at machines and workstations. Reference [34], on the other hand, classifies flexibility into three categories: necessary flexibility (machine flexibility, product flexibility, labour flexibility, materials handling flexibility, routing flexibility, volume flexibility), sufficient flexibility (process flexibility, operational flexibility, programme flexibility, materials flexibility) and competitive flexibility (production flexibility, expansion flexibility, market flexibility).

It can be concluded that the different types of flexibility defined within such classifications and addressed in the literature include:

- Product flexibility: the ability to add or substitute easily new parts [32].

- Volume flexibility: the ability of a manufacturing system to vary total production volume economically [35].

- Mix flexibility: the ability of a firm to produce different combinations of products economically and effectively [36].

- Machine flexibility: the ability of a machine to perform different types of operation without requiring a prohibitive effort in switching from one to another [32,37].

- Labour flexibility: the ability of the workforce to perform a broad range of manufacturing tasks economically and effectively [36].

- Market flexibility: the ability to adapt to a changing market environment easily [35].

- Process flexibility: the ability of a manufacturing system to process a given set of components with different processes, operations sequence and materials [38].

- New product flexibility: the ability of a manufacturing system to introduce and manufacture new parts and products [35].

- Expansion flexibility: the ability to increase capacity and capability easily when needed [32].

\subsubsection{Quality}

Quality is a competitive weapon in the marketplace. It 
engenders competitive advantage by providing products that meet or exceed customer needs and expectations [39]. Quality, as stated by [40], is defined using different perspectives, as it is a subjective goal that has indefinable characteristics. An early definition of quality is that of [41] as "fitness for use". The definition of [41] employs the customer's perspective in defining quality; it is the customer who decides what goods or services best satisfy his/her needs. A similar approach is taken by [42], who define quality as excellence, value, conformance to specifications and meeting or exceeding customers' expectations. The term "fitness for use," presented by [41], is included in the quality definition presented by [42]. Therefore, it can be concluded that the customer perspective is central to any definition of quality. Quality is, therefore, a multidimensional construct. Reference [43] identifies eight dimensions for quality as: performance, features, reliability, conformance, durability, serviceability, aesthetics and perceived quality. These dimensions match the customer perspective. Table 1 summarises a number of definitions of quality.

Thus, quality is clearly viewed as a main source of competitive advantage, by meeting customer requirements. Moreover, scholars have linked quality to competitive strategy. For example, [49] considers quality to be a reflection of the competitive strategy of firms. Reference [49] supports the notion that quality has gone through an evolutionary process; from an operational level to a strategic one, so quality should be adopted as a strategic goal in firms. In manufacturing strategy, therefore, quality is associated with both conformance to specifications and critical customer expectations [50]. In this context, [51] argues that firms which compete on quality can adopt a differentiation strategy and position

Table 1. Definitions of quality.

\begin{tabular}{|c|c|}
\hline Reference & Definition(s) of quality \\
\hline$[41]$ & Fitness for use. \\
\hline$[44]$ & Conformance to specifications. \\
\hline$[45]$ & $\begin{array}{l}\text { The total composite product and service characteristics } \\
\text { of marketing, engineering manufacture and } \\
\text { maintenance through which the product and services } \\
\text { in use will meet the expectations of customers. }\end{array}$ \\
\hline$[46]$ & $\begin{array}{l}\text { To practice quality control is to develop, design, } \\
\text { produce and service a quality product which is } \\
\text { most economical, most useful and always satisfactory } \\
\text { to the customer. }\end{array}$ \\
\hline [47] & $\begin{array}{l}\text { "Quality should be aimed at the needs of the } \\
\text { consumer, present and future". }\end{array}$ \\
\hline [43] & $\begin{array}{l}\text { There are eight dimensions of quality as defined } \\
\text { from the customer's viewpoint: performance, } \\
\text { features, reliability, conformance, durability, } \\
\text { serviceability, aesthetics, and perceived quality. }\end{array}$ \\
\hline [48] & $\begin{array}{l}\text { Quality is the ability to satisfy the needs and } \\
\text { expectations of customers. }\end{array}$ \\
\hline
\end{tabular}

their products based on several attributes which will lead to the ability to charge a premium price. Hence, quality helps firms to enhance their competitiveness and promotes customer loyalty by meeting customers' expectations. This conclusion leads a firm to view quality as a competitive weapon that should be adopted as a strategy with a major role in creating and sustaining its competitive advantage.

\subsubsection{Cost}

Competitive advantage, as argued by [51], can be achieved by adopting one or more of the following generic competitive strategies: 1) cost leadership in which the features of this strategy are: low cost relative to competitors, related and standardised products, and economies of scale. A cost leadership strategy requires intense supervision of labour, tight cost control, frequent and detailed control reports and structured firm and responsebility; 2) differentiation: this strategy is described in terms of product uniqueness, an emphasis on marketing and research, and a flexible structure; and 3) focus: this strategy implies a focus on a narrow strategic target (buyer group, product line or geographic market) through differentiation, low cost or both.

Reference [52] indicates that low cost manufacturing is the priority when profit margins are low. The logic behind linking a cost leadership strategy to competitive advantage, as suggested by [53], is that competitive advantage can be divided into two basic types: lower cost than rivals, or the ability to differentiate and command a premium price that exceeds the extra cost of doing so.

\subsubsection{Delivery}

Delivery is a competitive priority because customers are interested in satisfying their needs and wants in the right quantity at the right time. In this context, [54] states that "Delivery of the required function means ensuring that the right product (meeting the requirements of quality, reliability and maintainability) is delivered in the right quantity, at the right time, in the right place, from the right source (a vendor who is reliable and will meet commitments in a timely fashion), with the right service (both before and after sale), and, finally, at the right price". In the same vein, [55] argues that delivery capability is a time issue where it reflects the following concepts: the number of aspects of a firm's operations; how quickly a product or service is delivered to a customer; how reliably the products or services are developed and brought to the market; and the rate at which improvements in products and processes are made.

\subsection{Research Objective and Model}

The objective of this research can be summarised as 
follows:

Identifying the relationships between competitive priorities and competitive advantage in Jordanian manufacturing.

In the light of the arguments presented in Section 2, Figure 1 depicts the research model, which suggests that the competitive advantage of a firm is generated by four competitive priorities: quality, cost, flexibility and delivery. However, it has been argued that there is a link between quality and each of the two competitive strategies: cost leadership and differentiation. In this context, [28] points out:

- To compete via a cost leadership strategy, firms will put considerable effort into controlling production cost, increasing their capacity utilisation, controlling materials supply or product distribution and minimising other costs, including R\&D and advertising.

- To compete via a differentiation strategy, firms need to offer unique products which are characterised by valuable features, such as quality, innovation, the delivery system and a broad range of other factors.

- There is a link between quality and competitive strategy: quality is categorised as a primary basis for a differentiation strategy, as firms adopting this strategy will position their products uniquely, based on several attributes, leading to a premium price.

The aim of this research is to investigate the relationships between competitive priorities and competitive advantage, so the hypotheses to be tested are concerned with the extent to which the construct of competitive advantage is a function of each of the four competitive priorities: quality, cost, delivery and flexibility. The hypotheses are consistent with the objective of the research, which is concerned with predicting the relationships between competitive priorities and competitive advantage in Jordanian manufacturing firms. More specifically, the rationale for developing the research hypotheses is the general agreement among authors and researchers (e.g. $[8,26]$ on the existence of the above four major competitive priorities, all of which contribute to the creation of competitive advantage. Hence, the following hypotheses

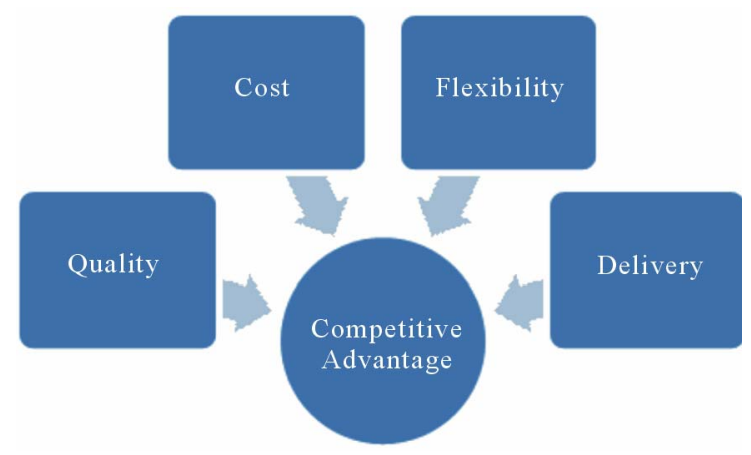

Figure 1. Research model. were formulated:

H1: Quality affects positively the creation of competitive advantage by a firm.

H2: A cost leadership reduction strategy affects positively the creation of competitive advantage by a firm.

H3: Delivery affects positively the creation of competitive advantage by a firm.

H4: Flexibility affects positively the creation of competitive advantage by a firm.

\section{Research Methodology}

In compliance with the suggestion of [29], a positivistic methodology was adopted, because of the need for quantitative data to satisfy the objectives of the research and the need for a large sample to carry out the data analysis. In addition, there was a need to examine the anticipated relationships depicted in the research model shown in Figure 1. The data collection method consisted of a questionnaire designed to test the model. A delivery and collection approach was used to distribute and collect the questionnaires, to ensure a high response rate and to take advantage of personal contact. This method is thought to enhance respondent participation. The survey instrument, as suggested by [56], was pre-tested with executives and academic experts, who were asked to review it for readability, ambiguity and completeness, and to evaluate whether individual items appeared to be appropriate measures of their respective constructs. This process led to several minor changes being made prior to generating the final version of the questionnaire. The questionnaire format was highly structured: all of its questions were fixed-response alternative questions that required respondents to select options on five-point Likert scales.

All of the measurement scales used, as shown in Table 2, were based on previous research. Assuring the validity and reliability of the measures required supporting literature to validate the scales which were used to operationalise the research constructs. The competitive advantage construct was measured using the scales and indices included in the work of [14], who used the following variables to determine level of competitiveness: market share, profits, returns, technological provision, financial management, quality of products/services, after-sales service, managers' educational background, customer loyalty, supplier loyalty, location of establishment, employees' commitment and loyalty, employees' professional know-how and firm's reputation. As shown in Table 2, competitive priorities were operationalised using measurement scales adapted from previous studies.

Jordanian manufacturing firms, classified as public shareholding firms on the Amman Stock Exchange were chosen as the target population, because the industrial sector clearly reflects the constructs of this research, in 
Table 2. Supporting literature for measurement scales.

\begin{tabular}{cc}
\hline Construct & Supporting literature for measurement scales \\
\hline Quality & {$[28,57]$} \\
Cost & {$[39,40]$} \\
Delivery & {$[40,57]$} \\
Flexibility & {$[32,36]$} \\
\hline
\end{tabular}

which variables are related to manufacturing rather than services. The sample targeted was the entire population, consisting of 88 industrial firms classified on the Amman Stock Exchange as industrial shareholding firms, according to its report for the year 2011. Individual distribution was used to administer the questionnaire, which was accompanied by a covering letter explaining the research objectives. The participants were asked to complete the questionnaires, which were collected later. The main reason for targeting the entire population was to ensure that the sample was representative and not biased.

Depending on the structure of firms, four to five questionnaires were delivered to each manufacturer and were given to its Director, Vice-President, Operations or Production Manager, Finance Manager and Marketing Manager. The respondents comprised 364 individuals in total, of whom 226 completed the questionnaires; 12 out of these responses were unusable. The number of usable questionnaires was 214 . The usable questionnaires were collected from executives with the titles of Director $(\mathrm{n}=$ $31)$, Vice-President $(n=32)$, Operations or Production Manager $(\mathrm{n}=56)$, Finance Manager $(\mathrm{n}=35)$ and Marketing Manager $(\mathrm{n}=60)$. These usable replies represented a response rate of 58.7 percent. The responding firms covered a wide range of manufacturing activities, including electronics, engineering products, electrical, chemicals and pharmaceuticals.

\section{Research Findings}

A reliability test was carried out using Cronbach's alpha, which measures the internal consistency of a construct. The recommended minimum acceptable limit of reliability for this measure, as reported by [58], is 0.60 . As shown in Table 3, all the constructs passed the reliability test.

As shown in Table 4, frequency and descriptive statistics were used to determine the relative importance of each of the competitive priorities in achieving competitive advantage.

The respondents indicated that their firms utilised different competitive priorities to maintain competitive advantage. It may be noted that each the competitive priorities shown in Table $\mathbf{4}$ has a mean above 3. So it may be concluded that all of competitive priorities are of considerable importance in Jordan.
Table 3. Values of Cronbach's alpha for the research constructs.

\begin{tabular}{cc}
\hline Construct & $\alpha$ Value \\
\hline Competitive advantage & 0.8214 \\
Quality & 0.7168 \\
Cost & 0.8990 \\
Delivery & 0.9226 \\
Flexibility & 0.8339 \\
\hline
\end{tabular}

Table 4. Descending means of the competitive priorities.

\begin{tabular}{ccc}
\hline Construct & Mean & Standard deviation \\
\hline Quality & 4.213 & 0.5537 \\
Cost & 3.270 & 0.7405 \\
Flexibility & 3.127 & 0.5793 \\
Delivery & 3.081 & 0.6726 \\
\hline
\end{tabular}

Multiple regression analysis was conducted to test the research hypotheses. Multiple regression identifies how much of the variance in the dependent variable is explained when a set of variables is able to predict a particular outcome. As shown in Table 5, Kurtosis and Skewness values were used to check the normality of each variable included in the research. Skewness values larger than $(+1)$ or smaller than $(-1)$, as suggested by [59], indicate a substantially skewed distribution. On the other hand, [60] added that a curve is too peaked when the Kurtosis exceeds $(+3)$ and is too flat when it is below $(-3)$. Thus, Skewness values within the range of $(-1)$ to $(+1)$ and Kurtosis values within the range of $(-3)$ to $(+3)$ indicate an acceptable range. As shown in Table 5, the values of Skewness and Kurtosis for each variable indicate that the research constructs fell within the acceptable range.

A multiple regression analysis was then conducted. The results are presented in Tables 6-8. Based on the research hypotheses, the four independent variables of quality, cost, delivery and flexibility were identified as predictor variables and one dependent or outcome variable (competitive advantage) was considered. The results of the multiple regression analysis, as shown in Table 6, reveal a coefficient of determination, $\mathrm{R}^{2}$, which predicts the relationship between the independent variables and dependent variable, of 0.775 . This means that 77.5 percent of the total variance in the dependent variable (competitive advantage) is accounted for by the independent variables (quality, cost, delivery and flexibility). This result provides confirmation of the significant role of the four competitive priorities in creating competitive advantage. 
Table 5. Skewness and Kurtosis for research constructs.

\begin{tabular}{ccc}
\hline Variable & Skewness & Kurtosis \\
\hline Quality & -1.041 & -0.477 \\
Competitive advantage & -0.691 & -0.275 \\
Cost & -0.580 & -0.933 \\
Flexibility & -0.962 & 0.224 \\
Delivery & 0.244 & 0.932 \\
\hline
\end{tabular}

Table 6. Model summary.

\begin{tabular}{cccc}
\hline Model & R & R Squared & Std. Error of the Estimate \\
\hline 1 & 0.880 & 0.775 & 0.4108 \\
\hline
\end{tabular}

Table 7. ANOVA results.

\begin{tabular}{ccccccc}
\hline \multirow{2}{*}{ Model } & & $\begin{array}{c}\text { Sum of } \\
\text { Squares }\end{array}$ & df & $\begin{array}{c}\text { Mean } \\
\text { Square }\end{array}$ & F & Sig. \\
\hline 1 & Regression & 128.155 & 4 & 32.039 & 189.873 & 0.000 \\
& Residual & 37.291 & 221 & 0.169 & & \\
& Total & 165.446 & 225 & & & \\
& & & & & & \\
\hline
\end{tabular}

Table 8. Results of multiple regression analysis.

\begin{tabular}{cccccc}
\hline & $\begin{array}{c}\text { Unstandardised } \\
\text { Coefficients }\end{array}$ & $\begin{array}{c}\text { Standardised } \\
\text { Coefficients }\end{array}$ & t & Sig. \\
\hline $\begin{array}{c}\text { Dependent } \\
\text { variable }\end{array}$ & B & Std. Error & Beta & & \\
(Constant) & -1.858 & 0.265 & & -7.002 & 0.000 \\
Quality & 0.841 & 0.069 & 0.568 & 12.216 & 0.000 \\
Cost & 0.398 & 0.062 & 0.312 & 6.451 & 0.000 \\
Delivery & 0.187 & 0.051 & 0.121 & 3.646 & 0.000 \\
Flexibility & 0.242 & 0.042 & 0.209 & 5.781 & 0.000 \\
\hline
\end{tabular}

Dependent Variable: Competitive advantage.

The results of the F-ratio, as shown in Table 7, suggest that the regression model is significant at $\mathrm{p}<0.001$. It can be concluded, therefore, that the regression model predicts competitive advantage well. In other words, the competitive priorities of quality, cost, flexibility and delivery (the independent variables) have the ability to predict competitive advantage (the dependent variable).

The regression analysis presented in Table 8 reveals that the creation of competitive advantage is determined by the competitive priorities of flexibility, quality, cost and delivery. Therefore, all the hypothesised relationships between competitive priorities and competitive advantage are accepted.

Table 9 summarises the research hypotheses and their results.
Table 9. Summary of research hypotheses and results.

\begin{tabular}{cllll}
\hline Hypothesis & Description & Beta & t-value & Comment \\
\hline H1 & $\begin{array}{l}\text { Quality affects positively } \\
\text { the creation of competitive } \\
\text { advantage by a firm. }\end{array}$ & 0.568 & 12.216 & Accepted \\
& $\begin{array}{l}\text { A cost leadership reduction } \\
\text { strategy affects positively } \\
\text { the creation of competitive } \\
\text { advantage by a firm. }\end{array}$ & 0.312 & 6.451 & Accepted \\
& $\begin{array}{l}\text { Delivery affects positively } \\
\text { the creation of competitive } \\
\text { advantage by a firm. }\end{array}$ & 0.121 & 3.646 & Accepted \\
H4 & $\begin{array}{l}\text { Flexibility affects positively } \\
\text { the creation of competitive } \\
\text { advantage by a firm. }\end{array}$ & 0.209 & 5.781 & Accepted \\
\hline
\end{tabular}

The multiple regression analysis, therefore, shows the existence of a significant positive relationship between each of the four independent variables (quality, cost, delivery and flexibility) and the dependent variable (competitive advantage). These results are congruent with the findings of previous empirical work. For example, [40] found significant relationships between quality, cost and flexibility and financial performance. The results are also consistent with the conclusion of [26] that quality, customer focus and delivery criteria are important priorities for enhancing manufacturing firms' competitiveness. It should be noted that each of the four competitive priorities (quality, cost, flexibility and delivery) contributes to improving and sustaining the competitive advantage of a firm, since such priorities are all linked to its corporate and functional strategies.

In this context, [61] supports the strategic link between manufacturing strategy and competitive priorities, noting that identifying manufacturers' competitive priorities has long been considered a key element in manufacturing strategy research. Operations managers, however, should consider the fact that each of the competitive priorities is a complex construct which ultimately affects the planning and implementation of the operations strategy of a firm by meeting the related organisational objectives. As a way of explanation, competing via a cost reduction leadership strategy leads firms to analyse the manufacturing cost-related categories including (direct) production costs, productivity, capacity utilisation and inventory reduction [61].

Similarly, quality as a competitive priority is a multidimensional construct. Reference [43] names eight dimensions of quality as defined from the customer's viewpoint: performance, features, reliability, conformance, durability, serviceability, aesthetics and perceived quality. In their comments on these dimensions, [61] emphasise the conformance dimension of quality. Reference [61] points out that the other dimensions represent possible bases of 
competition, but they require more inter-functional coordination among manufacturing, marketing, $R \& D$ and engineering than does achieving conformance quality. This conclusion leads us to think strategically about the mutual relationships among competitive priorities. Reference [62], furthermore, believes that the four competitive capabilities can be emphasised and enhanced simultaneously.

Since competitive advantage is enhanced by an increase in organisational performance, scholars such as [2] have linked competitive priorities to performance. The findings of [2] are consistent with literature (e.g. [63,64]) which suggests a correspondence between performance measures and the manufacturing priorities emphasised. The study deals with the four competitive priorities of cost, delivery, quality and flexibility in manufacturing strategy and its findings indicate that different groups of manufacturers (Do All, Speedy Conformers, Efficient Conformers and Starters) emphasise different sets of competitive priorities, even within the same industry. Further, the Do All types, who emphasise all four competitive priorities, seem to perform better on customer satisfaction than their counterparts in the Starters group. In summary, [2] suggests that different manufacturers use different bases to compete within the same industry.

Similarly, [65] examines the relationship between manufacturing strategy and competitive strategy and their influence on firm performance. The findings of [65] confirm that all four manufacturing strategies (cost, delivery, flexibility and quality) are means by which a firm can implement its competitive strategies and further that the competitive priorities are interrelated and correlated to one another. In this context, [65] identify the existence of strong relationships between competitive strategy and manufacturing strategy. In line with $[62,65]$ argue that improving quality can reduce manufacturing lead time, the amount of time spent on reworking and the quantity of materials rejected, thus contributing to improvements in flexibility, delivery times and unit cost efficiencies.

\section{Conclusions and Implications}

Managers need to deal with several types of competitive priority to construct a manufacturing strategy. Competitive priorities facilitate the creation of operations and manufacturing strategies to enhance the competitive advantage of a firm. The results of this study indicate, as hypothesised, that strong relationships exist between competitive priorities and competitive advantage. Managers, therefore, need to consider the following implications when planning the operations and manufacturing strategy of a firm: 1) quality positively affects the creation of competitive advantage; 2) cost leadership strategy affects positively the creation of competitive advantage;
3) delivery positively affects the creation of competitive advantage; and 4) flexibility positively affects the creation of competitive advantage.

It is interesting to note also that the four competitive priorities (flexibility, cost, quality and delivery) exist in most of the industries covered in the sample. This suggests that different manufacturers use different competitive priorities to compete within the same industry. In addition, it can be concluded that each priority affects the others. Providing products at high quality with fewer defects will enable a firm to compete via a cost leadership strategy by reducing set-up time and manufacturing cost. High quality products will also increase customers' loyalty to brands and help a firm to differentiate itself from others in competitive market segments. Flexibility as a multidimensional construct acts as a competitive weapon in the arsenal of any manufacturing or service firm when managing demand and capacity in response to changes related to customer needs and expectations. In addition, flexibility gives a firm the ability to handle variations in customer delivery schedule, to introduce new parts or new products quickly, to adjust capacity rapidly, to customise products and to handle changes in the product mix quickly. It may be concluded that competitive priorities are interrelated and correlated and that such priorities play a major role in creating, developing and sustaining the competitive advantage of a firm.

The findings of this research suggest that linking competitive priorities to competitive advantage is the master key for a firm to survive in a turbulent environment. Operational and marketing strategies should place emphasis on competitive priorities such as quality, cost, flexibility and delivery to achieve, develop and maintain competitive advantage. It would be of value to conduct more empirical studies into the impact of competitive priorities on the financial and nonfinancial performance of firms and into their role in planning various functional strategies, including those of manufacturing, operations, marketing and finance.

\section{REFERENCES}

[1] K. Mellahi and H. Sminia, "The Frontiers of Strategic Management Research," International Journal of Management Reviews, Vol. 11, No. 1, 2009, pp. 1-7. doi:10.1111/j.1468-2370.2008.00248.x

[2] R. Kathuria, "Competitive Priorities and Managerial Performance: A Taxonomy of Small Manufacturers," Journal of Operations Management, Vol. 18, No. 6, 2000, pp. 627-641. doi:10.1016/S0272-6963(00)00042-5

[3] M. Tracey, M. Vonderembse and J. Lim, "Manufacturing Technology and Strategy Formulation: Keys to Enhancing Competitiveness and Improving Performance," Journal of Operations Management, Vol. 17, No. 4, 1999, pp. 411-428. doi:10.1016/S0272-6963(98)00045-X 
[4] S. Li, B. Ragu-Nathan, T. Ragu-Nathan and S. Rao, "The Impact of Supply Chain Management Practices on Competitive Advantage and Organisational Performance," Omega, Vol. 34, No. 2, 2006, pp. 107-124. doi:10.1016/j.omega.2004.08.002

[5] H. Ma, "Creation and Preemption for Competitive Advantage," Management Decision, Vol. 37, No. 3, 1999, pp. 259-266. doi:10.1108/00251749910264497

[6] A. Harrison and R. Hoek, "Logistics Management and Strategy," Pearson Education, Upper Saddle River, 2002.

[7] T. Conner, "Managing for Competitiveness: A Proposed Model for Managerial Focus," Strategic Change, Vol. 12, No. 4, 2003, pp. 195-207. doi: $10.1002 /$ jsc. 633

[8] S. Wheelwright, "Manufacturing Strategy: Defining the Missing Link," Strategic Management Journal, Vol. 5, No. 1, 1984, pp. 77-91. doi:10.1002/smj.4250050106

[9] D. Passemard and B. Kleiner, "Competitive Advantage in Global Industries," Management Research News, Vol. 23, No. 7-8, 2000, pp. 111-117. doi:10.1108/01409170010782307

[10] M. Helms, "Perspectives on Quality and Productivity for Competitive Advantage," The TQM Magasine, Vol. 8, No. 3, 1996, pp. 5-10. doi:10.1108/09544789610118403

[11] R. Cardy and T. Selvarajan, "Competencies: Alternative Frameworks for Competitive Advantage," Business Horizons, Vol. 49, No. 3, 2006, pp. 235-245. doi:10.1016/i.bushor.2005.09.004

[12] D. Turner and M. Crawford, "Managing Current and Future Competitive Performers: The Role of Competency," In: G. Hamel and A. Heene., Eds., CompetencyBased Competition, Strategic Management Series, Wiley, 1994, pp. 241-254.

[13] G. Thornton and W. Byham, "Assessment Centres and Managerial Performance," Academic Press, New York, 1982.

[14] M. Molina, I. Pino and A. Rodriguez, "Industry, Management, Capabilities and Firms' Competitiveness: An Empirical Contribution," Managerial and Decision Economics, Vol. 25, No. 5, 2004, pp. 265-281. doi: $10.1002 / \mathrm{mde} .1148$

[15] J. Barney, "Firm Resources and Sustained Competitive Advantage," Journal of Management, Vol. 17, No. 1, 1991, pp. 99-120. doi:10.1177/014920639101700108

[16] J. Barney, "Strategic Factor Markets: Expectations, Luck and Business Strategy," Management Science, Vol. 32, No. 10, 1986, pp. 1231-1241. doi:10.1287/mnsc.32.10.1231

[17] M. Peteraf, "The Cornerstones of Competitive Advantage: A Resource-Based View," Strategic Management Journal, Vol. 14, No. 3, 1993, pp. 179-192. doi: $10.1002 / \mathrm{smj} .4250140303$

[18] A. Lockett, S. Thompson and U. Morgenstern, "The Development of the Resource-Based View of the Firm: A Critical Appraisal," International Journal of Management Reviews, Vol. 11, No. 1, 2009, pp. 9-28. doi:10.1111/j.1468-2370.2008.00252.x
[19] D. Teece, G. Pisano and A. Shuen, "Dynamic Capabilities and Strategic Management," Strategic Management Journal, Vol. 18, No. 7, 1997, pp. 509-533. doi:10.1002/(SICI)1097-0266(199708)18:7<509::AID-S MJ882>3.0.CO;2-Z

[20] D. Teece and G. Pisano, "The Dynamic Capabilities of Firms: An Introduction," Industrial and Corporate Change, Vol. 3, No. 3, 1994, pp. 537-556. doi:10.1093/icc/3.3.537-a

[21] G. Cepeda and D. Vera, "Dynamic Capabilities and Operational Capabilities: A Knowledge Management Perspective," Journal of Business Research, Vol. 60, No. 5, 2007, pp. 426-437.

doi:10.1016/j.jbusres.2007.01.013

[22] C. Heflat, S. Finkelstein, W. Mitchell, M. Peteraf, H. Singh, D. Teece and S. Winter, "Dynamic Capabilities: Understanding Strategic Change in Organisations," Blackwell, London, 2007.

[23] K. Eisenhardt and J. Martin, "Dynamic Capabilities: What Are They?" Strategic Management Journal, Vol. 21, No. 10-11, 2000, pp. 1105-1121.

doi:10.1002/1097-0266(200010/11)21:10/11<1105::AIDSMJ133>3.0.CO;2-E

[24] L. Krajewski and L. Ritzman, "Operations Management: Strategy and Analysis," 3rd Edition, Addison-Wesley, Boston, 1993.

[25] K. Phusavat and R. Kanchana, "Competitive Priorities of Manufacturing Firms in Thailand," Industrial Management and Data Systems, Vol. 7, No. 7, 2007, pp. 979-996. doi:10.1108/02635570710816702

[26] K. Boyer and M. Lewis, "Competitive priorities: Investigating the Need for Trade-Offs in Operations Strategy," Production and Operations Management, Vol. 11, No. 2, 2002, pp. 9-20.

[27] M. Mandelbaum, "Flexibility in Decision Making: An Exploration and Unification," Ph.D. Thesis, Department of Industrial Engineering, University of Toronto, Toronto, 1978.

[28] D. Zelenovich, "Flexibility: A Condition for Effective Production Systems," International Journal of Production Research, Vol. 20, No. 3, 1982, pp. 319-337. doi:10.1080/00207548208947770

[29] J. Nakane and R. Hall, "Holonic Manufacturing: Flexibility-The Competitive Battle in the 1990s," Production Planning and Control, Vol. 2, No. 1, 1991, pp. 2-13. doi: $10.1080 / 09537289108919325$

[30] D. Upton, "The Management of Manufacturing Flexibility," California Management Review, Vol. 36, No. 2, 1994, pp. 72-89. doi: $10.2307 / 41165745$

[31] H. Corrêa, "The Links between Uncertainty, Variability of Outputs and Flexibility in Manufacturing Systems," Ph.D. Thesis, School of Industrial and Business Studies, University of Warwick, Warwick, 1992.

[32] A. Sethi and S. Sethi, "Flexibility in Manufacturing: A Survey," International Journal of Flexible Manufacturing Systems, Vol. 2, No. 4, 1990, pp. 289-328. doi:10.1007/BF00186471

[33] J. Buzacott, "The Fundamental of Flexibility in Manu- 
facturing Systems," Proceedings of 1st International Conference on FMS, Brighton, 1982, pp.13-22.

[34] R. Narian, R. Yadav, J. Sarkis and J. Cordeiro, "The Strategic Implications of Flexibility in Manufacturing Systems," International Journal of Agile Management Systems, Vol. 2, No. 3, 2000, pp. 202-213. doi:10.1108/14654650010356112

[35] A. Das, "Towards Theory Building in Manufacturing Flexibility," International Journal of Production Research, Vol. 39, No. 18, 2001, pp. 4153-4177. doi:10.1080/00207540110072281

[36] Q. Zhang, M. Vonderembse and J. Lim, "Manufacturing Flexibility: Defining and Analysing Relationships among Competence, Capability, and Customer Satisfaction," Journal of Operations Management, Vol. 21, No. 2, 2003, pp. 173-191. doi:10.1016/S0272-6963(02)00067-0

[37] Y. Gupta and T. Somers, "Business Strategy, Manufacturing Flexibility, and Organisational Performance Relationships: A Path Analysis Approach," Production and Operations Management, Vol. 5, No. 3, 1996, pp 204-233. doi:10.1111/j.1937-5956.1996.tb00395.x

[38] I. Chen, R. Calantone and C. Chung, "The MarketingManufacturing Interface and Manufacturing Flexibility," Omega, Vol. 20, No. 4, 1992, pp. 431-443. doi:10.1016/0305-0483(92)90018-3

[39] C. Lee and X. Zhou, "Quality Management and Manufacturing Strategies in China," International Journal of Quality and Reliability Management, Vol. 17, No. 8, 2000, pp. 876-898. doi:10.1108/02656710010325101

[40] H. Kazan, G. Ozer and A. Cetin, "The Effect of Manufacturing Strategies on Financial Performance," Measuring Business Excellence, Vol. 10, No. 1, 2006, pp. 14-26. doi:10.1108/13683040610652186

[41] J. Juran, "Quality Control Handbook," McGraw-Hill, New York, 1974.

[42] C. Reeves and D. Bednar, "Defining Quality: Alternatives and Implications," Academy of Management Review, Vol. 19, No. 3, 1994, pp. 419-445.

[43] D. Garvin, "Competing on the Eight Dimensions of Quality," Harvard Business Review, Vol. 65, No. 6, 1987, pp. 101-109.

[44] P. Crosby, "Quality is Still Free: Making Quality Certain in Uncertain Times," McGraw-Hill, New York, 1996.

[45] A. Feigenbaum, "Total Quality Control," 3rd Edition, McGraw-Hill, New York, 1991.

[46] K. Ishikawa, "Introduction to Quality Control," JUSE Press, Tokyo, 1989.

[47] W. Deming, "Out of the Crisis," Massachusetts Institute of Technology Centre for Advanced Engineering Study, Cambridge, 1986.

[48] B. Bregman and B. Klefsjo, "Quality, from Customer Needs to Customer Satisfaction," McGraw-Hill, London, 1994.

[49] D. Parajogo, "The Relationship between Competitive Strategies and Product Quality," Industrial Management and Data Systems, Vol. 107, No. 1, 2007, pp. 69-83.

\section{doi:10.1108/02635570710719061}

[50] J. Miltenburg, "Manufacturing Strategy: How to Formulate and Implement a Winning Plan," Productivity Press, New York, 1995.

[51] M. Porter, "Competitive Strategy: Techniques for Analysing Industries and Competitors," Free Press, New York, 1980.

[52] T. Hill, "Manufacturing Strategy: Text and Cases," John Wiley and Sons, New York, 1994.

[53] M. Porter, "Towards a Dynamic Theory of Strategy," Strategic Management Journal, Vol. 12, No. 8, 1991, pp. 95-117. doi: $10.1002 / \mathrm{smj} .4250121008$

[54] K. Kumar and U. Kumar, "A Conceptual Framework for the Development of a Service Delivery Strategy for Industrial Systems and Products," Journal of Business and Industrial Marketing, Vol. 19, No. 5, 2004, pp. 310-319. doi: $10.1108 / 08858620410549938$

[55] L. Li, "Manufacturing Capability Development in a Changing Business Environment," Industrial Management and Data Systems, Vol. 100, No. 6, 2000, pp. 261270. doi:10.1108/02635570010301188

[56] D. Dillman, "Mail and Telephone Surveys: The Total Design Method," Wiley, New York, 1978.

[57] T. Burgess, H. Gules, J. Gupta and M. Tekin, "Competitive Priorities, Process Innovations and Time-Based Competition in the Manufacturing Sectors of Industrialising Economies: The Case of Turkey," Benchmarking for Quality Management and Technology, Vol. 5, No. 4, 1998, pp. 304-316.

[58] U. Sekaran, "Research Methods for Business: A Skill Building Approach," 4th Edition, John Wiley and Sons, New York, 2003.

[59] J. Hair, B. Babin, A. Money and P. Samouel, "Essentials of Business Research Methods," Lehigh Publishing, 2003.

[60] J. Hair, R. Anderson, R. Tatham and W. Black, "Multivariate Data Analysis," 5th Edition, Prentice-Hall, Upper Saddle River, 1998.

[61] P. Ward, J. McCreery, L. Ritzman and D. Sharma, "Competitive Priorities in Operations Management," Decision Sciences, Vol. 29, No. 4, 1998, pp. 1035-1046. doi:10.1111/j.1540-5915.1998.tb00886.x

[62] K. Ferdows and A. De Meyer, "Lasting Improvements in Manufacturing Performance: In Search of a New Theory," Journal of Operations Management, Vol. 9, No. 2, 1990, pp 168-184. doi:10.1016/0272-6963(90)90094-T

[63] A. Roth, "Linking Manufacturing Strategy and Performance: An Empirical Investigation," 49th Annual Meeting of the Academy of Management, Washington, 13-16 August 1989.

[64] P. Nemetz, "Bridging the Strategic Outcome Measurement Gap in Manufacturing Organisations," In: J. Ettlie, M. Burstein and A. Fiegenbaum, Eds., Manufacturing Strategy, Kluwer, Alphen aan den Rijn, 1990, pp. 63-74.

[65] K. Amoako-Gyampah and M. Acquaah, "Manufacturing Strategy, Competitive Strategy and Firm Performance: 
An Empirical Study in a Developing Economy Environment," International Journal of Production Economics,
Vol. 111, No. 2, 2008, pp. 575-592.

doi:10.1016/j.ijpe.2007.02.030 